\title{
Structural and Pharmacological Properties of Alkaloids with Special Reference to Thebaine Type Alkaloids
}

\author{
Tugba Taskin Tok ${ }^{1}$ and Sivakumar JT Gowder ${ }^{2,3 *}$ \\ ${ }^{1}$ Department of Chemistry, Gaziantep University, 27310, Gaziantep, Turkey \\ ${ }^{2}$ Department for Management of Science and Technology Development, Ton Duc Thang University, Vietnam \\ ${ }^{3}$ Faculty of Applied Sciences, Ton Duc Thang University, Vietnam \\ *Corresponding author: Sivakumar JT Gowder, Department for Management of Science and Technology Development, Ton Duc \\ Thang University, Ho Chi Minh City, Faculty of Applied Sciences, Vietnam, email: sivakumargowder@tdtu.edu.vn
}

\begin{tabular}{|c|c|}
\hline ARTICLE INFO & ABSTRACT \\
\hline Received: 幽 April 10, 2019 & \multirow{8}{*}{$\begin{array}{l}\text { Alkaloids are pharmacologically active compounds and have a wide array of ther- } \\
\text { apeutic value. Though they exhibit medicinal properties, we need to evaluate the ad- } \\
\text { verse effects of alkaloids though their structural pharmacological properties. By using a } \\
\text { Diels-Alder reaction (D-A), we identified novel D-A adducts, obtained with thebaine and } \\
\text { various dienophiles, benzylidene malononitrile }(1-28) \text { and metilen malononitrile }(29-38) \\
\text { include heteroaromatic rings. Gaussian09 and Discovery Studio } 3.5 \text { softwares were per- } \\
\text { formed from basic to advance basis sets for these compounds by using quantum chemical } \\
\text { descriptors such as electrophilicity index, }(\omega) \text {, global hardness }(\eta) \text { and electronic charge } \\
(\Delta \mathrm{N}) \text { to predict the probable chemical and biochemical activities of thebaine derivatives. } \\
\text { The endo forms of } 2-(4 \text {-nitrobenzylidene)malononitrile, }(0-4 \text { and p-5) display significant- } \\
\text { ly high tendency in the electrophilicity index }(\omega) \text { and electronic charge }(\Delta N) \text { values. }\end{array}$} \\
\hline Published: April 24, 2019 & \\
\hline Citation: Tugba $\mathrm{T}$ T, Sivakumar J & \\
\hline G. Structural and Pharmacological & \\
\hline Properties of Alkaloids with Special & \\
\hline Reference to Thebaine Type Alka- & \\
\hline loids. Biomed J Sci \& Tech Res 17(3)- & \\
\hline 2019. BJSTR. MS.ID.002993. & \\
\hline $\begin{array}{l}\text { Keywords: Alkaloids; Cytotoxicity; } \\
\text { Diels-Alder Reaction; Inhibitors; } \\
\text { Thebaine }\end{array}$ & $\begin{array}{l}\text { Abbreviations: } \mathrm{D}-\mathrm{A}=\text { Diels-Alder reaction; } \omega=\text { Electrophilicity index; } \eta=\text { Global hard- } \\
\text { ness; } \Delta \mathrm{N}=\text { Electronic charge; } \mathrm{E}=\text { Total energy; HOMO = The energy of the highest occu- } \\
\text { pied molecular orbital; LUMO = The energy of the lowest unoccupied molecular orbital; } \\
\text { DM = Dipole moments; G09 = Gaussian 09; DS } 3.5=\text { Discovery studio 3.5; MMN = 2-meth- } \\
\text { ylenemalononitrile }\end{array}$ \\
\hline
\end{tabular}

\section{Introduction}

\section{Alkaloids}

Alkaloids are pharmacologically active with two or more fused organic compounds including heteroatoms in it. These atoms determine the properties of alkaloids. Especially, an alkaloid containing one or more nitrogen atoms as primary or another form of amines may provide basicity to the alkaloid. Alkaloids are found mainly in plants, but to the lesser extent in animals and microorganisms [1]. Many alkaloids are toxic, but they often have pharmacological effects. Extraction of alkaloids from plants has been widely used by researchers for therapeutic and recreational purposes. For example, Ephedra, opium poppies, and cocoa leaves have been used medicinally since ancient times. In the nineteenth century, alkaloids were first isolated successfully, and alkaloidcontaining drugs were marketed [2]. The structure of the first alkaloid, namely coniine, was established in the year 1870 by Schiff. Catharanthus alkaloids and paclitaxel came into the market as researchers looked for plant drugs with anticancer properties.

Alkaloids are optically active, bitter in taste (except papaverine), levorotatory (exception is coniine, which is dextrorotatory), colourless (except berberine which is yellow, and harmaline and betanidine, which are reddish), crystalline solids (except nicotine and coniine, which are liquids), and soluble in organic solvents. They are basic and form salts with the acids; some of the alkaloids form as salts called quaternary amines (e.g. cinchona alkaloids 
with quininic acid), while some exist as free bases (e.g. nicotine). Alkaloids also exist as glycosides (e.g. solanum alkaloids) and esters (e.g. atropine). The biological activity of the alkaloids frequently depends on the amine function being transferred into a quaternary amine at physiological $\mathrm{pH}$ by protonation. In summary, alkaloids behave as curare or arrow poisons. Curare alkaloids, which have muscle relaxant properties, are the active ingredients of arrow poisons used by South American Indians.

\section{Alkaloids as Medicines}

In general, many alkaloids are pharmacologically active substances which possess various physiological activities in humans and animals. The use of alkaloids containing plants as dyes, drugs, or poisons can be traced back almost to the beginning of civilization [3]. Opium that derived from Papaver somniferum L. was used as medicine in ancient Greece, Egypt and Rome. More recently, China learned about it via Arabian traders in the eighth century A.D. Today, a lot of alkaloids are still in use as drugs, against their poisonous effects. Caffeine, mostly obtained from the decaffeination of coffee species, is used a psychostimulant reagent. Codeine is used as an antitussive. Cocaine is used as a local anesthetic, especially for eye surgery. Morphine is an indispensable analgesic reagent that is used for the treatment of severe pain.

\section{Classification of Alkaloids}

Alkaloids containing wide families are classified using different techniques [4]. These techniques: Pharmacological classification is based on the clinical use or pharmacological activity (analgesic and cardioactive alkaloids). Taxonomic classification is based on the family or genus (rauwolfia and cinchona alkaloids). Biosynthetic classification is also based on the type of precursors or building block compounds used by plants to synthesize alkaloids (morphine, papaverine, narcotine and colchicine may be listed as phenylalanine- and tyrosine-derived bases). The last one, chemical classification, is based on the chemical structure of the alkaloid. (Thebaine, for example, is an isoquinoline derivative alkaloids of opium; aspidospermine is an indole alkaloid.). Alkaloids are often classified on the basis of chemical structure. These groups are described in Figure 1.

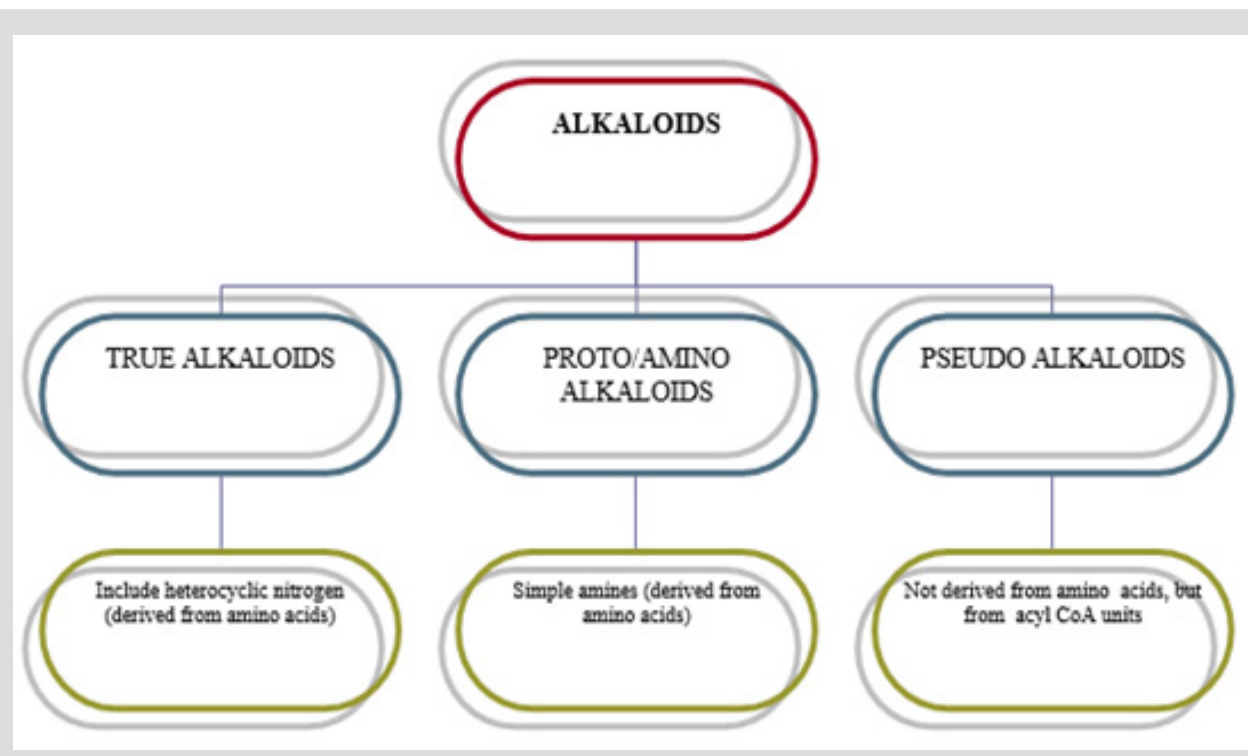

Figure 1: Chemical classification of alkaloids.

\section{Opioid Structure}

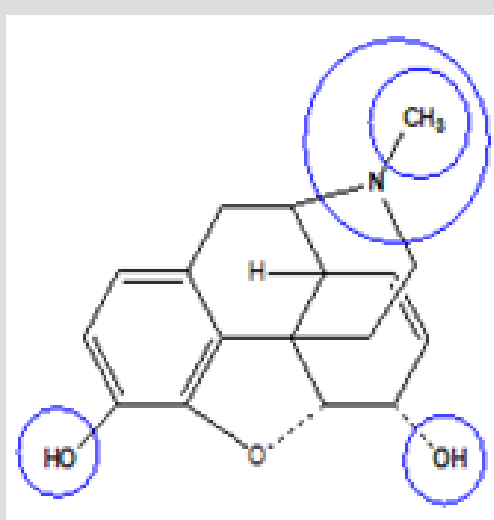

Morphine

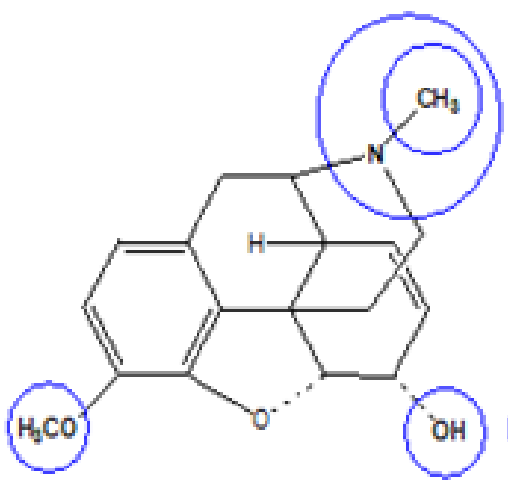

Codeine

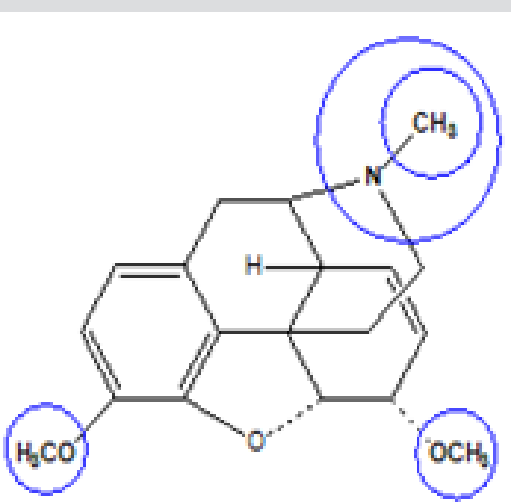

T bebaine

Figure 2: Structures of morphine, codine and thebaine. 
Morphine includes a benzene ring with a phenolic hydroxyl group at 3-position, an alcohol hydroxyl group at 6-position, and the nitrogen atom in Figure 2. When both hydroxyl groups are converted to ethers, codeine and thebaine as morphine derivatives are obtained. The tertiary form of the nitrogen appears to be crucial to the analgesic properties of morphine. The nitrogen quaternary widely decreases the analgesia, since morphine cannot pass into the central nervous system. Also, if the methyl group on the nitrogen is changed, it will again decrease analgesia. Morphine is also optically active, and only the levorotatory isomer exhibits the analgesic effect. Furthermore, they have many effects on the central nervous system. These are analgesia, respiratory depression, euphoria, and depression of cough reflex. Morphine undergoes strong first-pass metabolism by the liver if taken orally, limiting the effective time of analgesia, unless a sustained-release form is given [5]. The adverse effects of morphine include CNS respiration depression, sedation, dizziness, nausea, vomiting, itching, and constipation. CNS respiratory depression is the serious one among other complications.

Apart from these severe effects, morphine is still considered to be the most effective drug clinically available for the management of severe pain associated with cancer. The opium poppy was cultivated in Mesopotamia around $3400 \mathrm{BC}$. Opium is a mixture of alkaloids from the poppy seed. Opiates are naturally occurring alkaloids such as morphine or codeine. An opioid is a term used broadly to describe all compounds that work at the opioid receptors [6]. The common term narcotic (from the Greek word for stupor) originally was used to describe medications for sleep, and then was used to describe opioids, but now is a legal term for drugs that are abused.

\section{Opioid Receptors}

\section{Definition of an Opioid Receptor}

Thus, the opioid is a substance that produces the above-listed effects by acting at opioid receptors and whose actions are reversed by naloxone.

a) Extraction/purification of active poppy ingredient: morphine [7].

b) Effects: analgesia, respiratory depression, somnolence, decreased GI motility.

c) Agonist structure-activity relationships: morphine $\geq$ meperidine $>$ codeine $>0$

d) Structurally similar agents such as naloxone act as antagonists; have no effect alone but reverse the effects of an agonist.

e) Opioid binding interactions showed high-affinity binding sites.

\section{Opioid Receptor Subtypes}

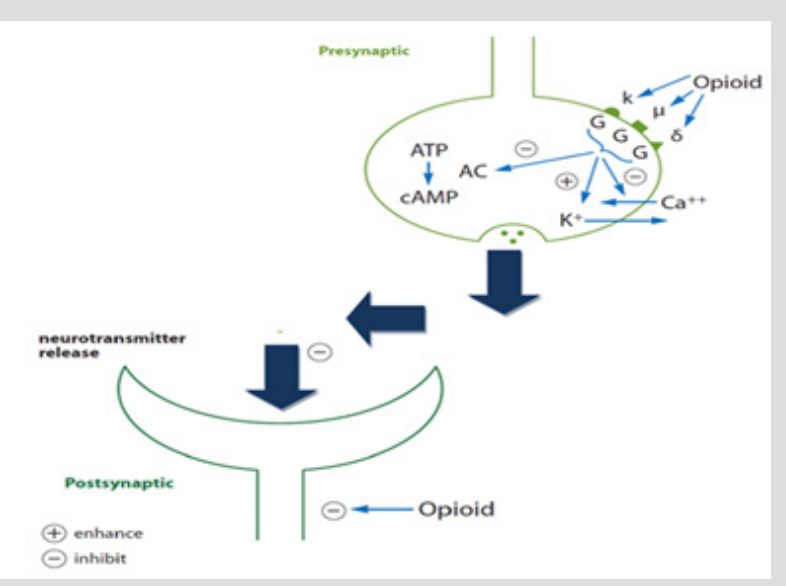

Figure 3: Locations of opioid receptors [kappa $(\kappa), \mathrm{mu}(\mu)$ and delta $(\partial)]$.

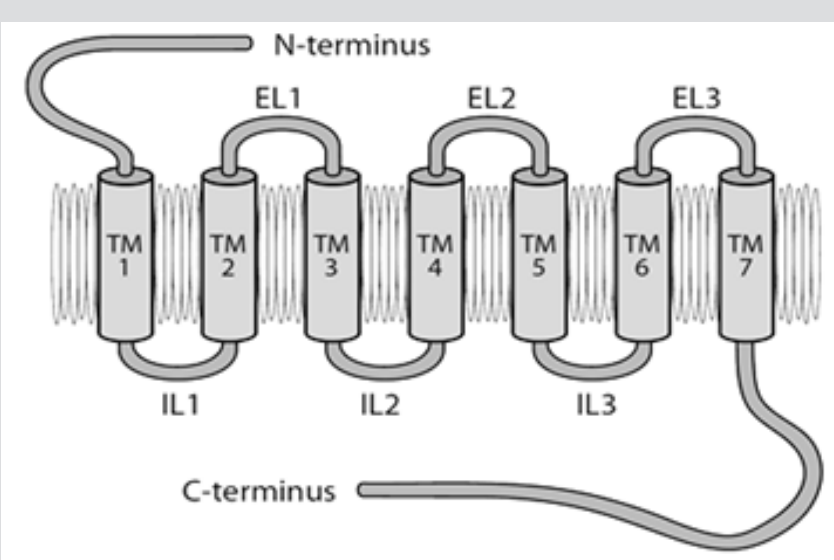

Figure 4: Opioid receptor structure. EL: Extracellular loop, TM: Transmembrane helix, IL: Intracellular loop [8]. 
Three types of opioid receptors have been identified so far: mu $(\mu)$ receptors, delta $(\partial)$ receptors, and kappa $(\kappa)$ receptors (Figures 3 \& 4). $\mathrm{Mu}(\mu)$ (agonist morphine) Mu receptors are found mainly in the nervous system (brainstem and medial thalamus). Mu receptors are responsible for respiratory depression, supraspinal analgesia, sedation, euphoria, sedation, decreased gastrointestinal motility, and physical dependence. Subtypes of Mu receptors possess Mu1 and Mu2. Mu1 is confined to analgesia, euphoria, and serenity, while $\mathrm{Mu} 2$ is concerned with respiratory depression, prolactin release, pruritus, dependence, anorexia, and sedation. These receptors are called OP3 or MOR (morphine opioid receptors). Kappa ( $\kappa$ ) (agonist ketocyclazocine) Kappa receptors are found in the limbic and other diencephalic areas, brain stem, and spinal cord, and induce spinal analgesia, sedation, dyspnea, dependence, dysphoria, and respiratory depression. These are also known as OP2 or KOR (kapa opioid receptors). Delta $(\delta)$ (agonist delta-alanine-delta-leucineenkephalin) Delta receptors are noticed in the brain, and their effects are not clearly explored.
They may be responsible for psychomimetic and dysphoric effects. They are also called OP1 and DOR (delta opioid receptors). Sigma $(\sigma)$ (agonist $\mathrm{N}$-allyl nor metazocine) Sigma receptors are associated with psychomimetic effects, dysphoria, and stressinduced depression. They are not included as opioid receptors, but rather are the target sites for phencyclidine (PCP) and its analogs.

These receptor types are defined by:

1) Agonist structure-activity relationships in the bioassay (ability to block stimulated contraction of specific smooth muscle tissues) and binding (Table 1).

2) Antagonist activity profile: naloxone blocks all opioid receptors (Table 1).

3) Lack of cross-tolerance.

4) Cloning

Table 1: Analgesic Effects of Opiod Receptors.

\begin{tabular}{|c|c|c|c|}
\hline & $\operatorname{Mu}(\mu)$ & Delta $(\delta)$ & Карра (к) \\
\hline & $\begin{array}{l}\text { Mu 1- Analgesia } \\
\text { Mu 1- Sedation, vomiting, } \\
\text { respiratory depression, pruritus, } \\
\text { euphoria, anorexia, urinary } \\
\text { retention, physical dependence. }\end{array}$ & Analgesia, spinal analgesia & $\begin{array}{l}\text { Analgesia, sedation, dyspnea, } \\
\text { psychomimetic effects, miosis, } \\
\text { respiratory depressions, euphoria, } \\
\text { dysphoria, dyspnea. }\end{array}$ \\
\hline \multicolumn{4}{|c|}{ Endogenous Peptides } \\
\hline Enkephalins & Agonist & Agonist & \\
\hline Beta Endorphin & Agonist & Agonist & \\
\hline Dynorphin A & Agonist & & Agonist \\
\hline \multicolumn{4}{|c|}{ Agonists } \\
\hline Morphine & Agonist & & Weak agonist \\
\hline Codeine & Weak agonist & Weak agonist & \\
\hline Fentanyl & Agonist & & \\
\hline Meperidine & Agonist & Agonist & \\
\hline Methadone & Agonist & & \\
\hline \multicolumn{4}{|c|}{ Antagonists } \\
\hline Naloxone & Antagonist & Weak antagonist & Antagonist \\
\hline Naltrexone & Antagonist & Weak antagonist & Antagonist \\
\hline
\end{tabular}

\section{Opioid Classes}

Opioid Classes DEA (Drug Enforcement Agency) classified opioids into schedules as illustrated in Table 2 and Table 3. Four chemical classes of opioids (Figure 5): Phenanthrenes are the prototypical opioids. The presence of a 6-hydroxyl is associated with nausea and hallucinations. Morphine and codeine (both with 6-hydroxyl groups) are associated with more nausea than hydromorphone and oxycodone (which do not possess 6-hydroxyl groups). Opioids in this group include morphine, codeine, hydromorphone, levorphanol, oxycodone, hydrocodone, oxymorphone, buprenorphine, nalbuphine, and butorphanol. Benzomorphans have pentazocine as a member of this class and is an agonist/antagonist with a high incidence of dysphoria. Phenylpiperidines cover fentanyl, alfentanil, sufentanil, and meperidine. Fentanyl has a strong affinity for the mu receptor. Diphenylheptanes include methadone and propoxyphene. Tramadol does not come under standard opioid classes. Tramadol is an atypical opioid, a 4-phenyl-piperidine analogue of codeine, with partial mu-agonist activity, in addition to central GABA, catecholamine, and serotonergic activities. 


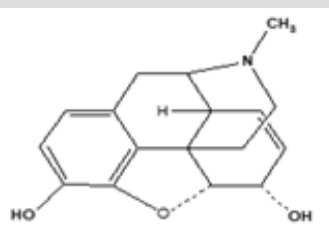

Phenanthrenes

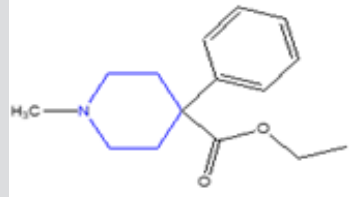

Pheaylpiperidines

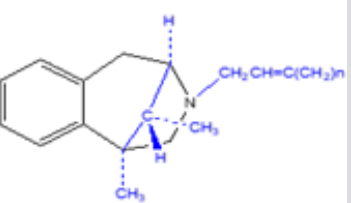

Benzomorphans

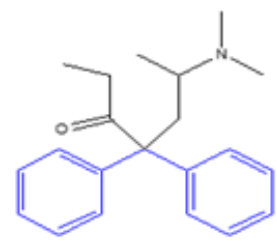

Diphenyllheptanes

Figure 5: Chemical classes of opioid.

Table 2: The Drug Enforcement Agency Program of Controlled Drugs.

\begin{tabular}{|c|c|c|c|c|}
\hline Program & Medical Use & Addiction Potential & Abuse Potential & Examples \\
\hline 1 & - & +++ & & Heroin, marijuana \\
\hline 2 & + & +++ & & Morphine, methadone \\
\hline 3 & + & ++ & & Hydrocodone, codein \\
\hline 4 & + & & + & $\begin{array}{l}\text { Benzodiazepines, } \\
\text { butorphanol }\end{array}$ \\
\hline 5 & + & & + & $\begin{array}{l}\text { Buprenex, phergan with } \\
\text { codein }\end{array}$ \\
\hline
\end{tabular}

Table 3: The Drug Enforcement Agency Program of Common Medications.

\begin{tabular}{|c|c|c|c|c|c|}
\hline & 1 & 2 & 3 & 4 & 5 \\
\hline Opioid Agonists & $\begin{array}{c}\text { Benzylmorphine } \\
\text { Dihydromorphinone } \\
\text { Heroin } \\
\text { Ketobemidone } \\
\text { Levomoramide } \\
\text { Nicocodeine } \\
\text { Nicomorphine } \\
\text { Racemoramide }\end{array}$ & $\begin{array}{c}\text { Codeine } \\
\text { various } \\
\text { Fentanyl } \\
\text { Sublimaze } \\
\text { Hydrocodone } \\
\text { Hydromorphone } \\
\text { Dilaudid } \\
\text { Meperidine } \\
\text { Demerol } \\
\text { Methadone } \\
\text { Morphine } \\
\text { Oxycodon } \\
\text { Oxymorphone } \\
\text { Numorphan }\end{array}$ & $\begin{array}{l}\text { Buprenorphine } \\
\text { Buprenex } \\
\text { Subutex } \\
\text { Codeine } \\
\text { compounds } \\
\text { Hydrocodone } \\
\text { compounds } \\
\text { Lorcet } \\
\text { Lortab } \\
\text { Tussionex }\end{array}$ & $\begin{array}{c}\text { Propoxyphene } \\
\text { Darvon } \\
\text { Darvocet }\end{array}$ & $\begin{array}{l}\text { Opium } \\
\text { preparations } \\
\text { Donnagel PG } \\
\text { Kapectolin }\end{array}$ \\
\hline $\begin{array}{l}\text { Mixed Agonist- } \\
\text { Antagonists }\end{array}$ & & & $\begin{array}{c}\text { Buprenorphine } \\
\text { + naloxone } \\
\text { Suboxone }\end{array}$ & $\begin{array}{c}\text { Pentazocine } \\
\text { naloxone } \\
\text { Talwin-Nx }\end{array}$ & \\
\hline Stimulants & $\begin{array}{c}\text { N-methylamphetamine } \\
\text { 3,4-methylenedioxy } \\
\text { amphetamine } \\
\text { MDMA, Ecstasy }\end{array}$ & $\begin{array}{c}\text { Amphetamine } \\
\text { Adderall } \\
\text { Cocaine } \\
\text { Dextro } \\
\text { amphetamine } \\
\text { Dexedrine } \\
\text { Desoxyn } \\
\text { Methylphenidate } \\
\text { Concerta } \\
\text { Metadate } \\
\text { Ritalin } \\
\text { Phenmetrazine } \\
\text { Fastin } \\
\text { Preludin }\end{array}$ & $\begin{array}{c}\text { Benzphetamine } \\
\text { Didrex } \\
\text { Pemoline } \\
\text { Cylert } \\
\text { Phendimetrazine } \\
\text { Plegine }\end{array}$ & $\begin{array}{l}\text { Diethylpropion } \\
\text { Tenuate } \\
\text { Fenfluramine } \\
\text { Phentermine } \\
\text { Fastin }\end{array}$ & $\begin{array}{l}\text { 1deoxyephedrine } \\
\text { Vicks Inhaler® }\end{array}$ \\
\hline
\end{tabular}




\begin{tabular}{|c|c|c|c|c|c|}
\hline $\begin{array}{c}\text { Hallucinogens, } \\
\text { Other }\end{array}$ & $\begin{array}{c}\text { Lysergic acid } \\
\text { diamine } \\
\text { Marijuana } \\
\text { Mescaline } \\
\text { Peyote } \\
\text { Phencyclidine } \\
\text { PCP } \\
\text { Psilocybin } \\
\text { Tetrahydrocannabinols }\end{array}$ & & $\begin{array}{c}\text { Dronabinol } \\
\text { Marinol }\end{array}$ & & \\
\hline $\begin{array}{l}\text { Sedative- } \\
\text { Hypnotics }\end{array}$ & $\begin{array}{c}\text { Methaqualone } \\
\text { Quaalude } \\
\text { Gamma-hydroxy } \\
\text { butyrate } \\
\text { GHB }\end{array}$ & $\begin{array}{c}\text { Amobarbital } \\
\text { Amytal } \\
\text { Glutethimide } \\
\text { Doriden } \\
\text { Pentobarbital } \\
\text { Nembutal } \\
\text { Secobarbital } \\
\text { Seconal }\end{array}$ & $\begin{array}{c}\text { Butabarbital } \\
\text { Butisol } \\
\text { Butalbital } \\
\text { Fiorecet } \\
\text { Fiorinal } \\
\text { Methyprylon } \\
\text { Noludar }\end{array}$ & $\begin{array}{c}\text { Alprazolam } \\
\text { Xanax } \\
\text { Chlordiazepoxide } \\
\text { Librium } \\
\text { Chloral betaine } \\
\text { Chloral hydrate } \\
\text { Noctec } \\
\text { Clonazepam } \\
\text { Klonopin } \\
\text { Clorazepate } \\
\text { Tranxene } \\
\text { Diazepam } \\
\text { Valium } \\
\text { Estazolam } \\
\text { Prosom } \\
\text { Ethchlorvynol } \\
\text { Placidyl } \\
\text { Ethinamate } \\
\text { Flurazepam } \\
\text { Dalmane } \\
\text { Halazepam } \\
\text { Paxipam } \\
\text { Lorazepam } \\
\text { Ativan } \\
\text { Mazindol } \\
\text { Sanorex } \\
\text { Mephobarbital } \\
\text { Mebaral } \\
\text { Meprobamate } \\
\text { Equanil } \\
\text { Methohexital } \\
\text { Brevital } \\
\text { Sodium } \\
\text { Methylphenobarbital } \\
\text { Midazolam } \\
\text { Versed } \\
\text { Oxazepam } \\
\text { Serax } \\
\text { Paraldehyde } \\
\text { Phenobarbital } \\
\text { Luminal } \\
\text { Prazepam } \\
\text { Centrax } \\
\text { Temazepam } \\
\text { Restoril } \\
\text { Triazolam } \\
\text { Halcion } \\
\text { Zaleplon } \\
\text { Sonata } \\
\text { Zolpidem } \\
\text { Ambien }\end{array}$ & $\begin{array}{c}\text { Diphenoxylate } \\
\text { preparations } \\
\text { Lomotil }\end{array}$ \\
\hline
\end{tabular}

Opioids can be classified agonist, agonist-antagonist, partial agonist, or partial antagonist. Compounds can have intrinsic affinity and efficacy at receptors, with affinity being a measure of the strength of interaction between a compound and its receptor and efficacy being a measure of the strength of activity. An agonist has both affinity and efficacy; an antagonist has affinity but no efficacy; a partial agonist has affinity but only partial efficacy. Regarding the opioids, the relevant receptors are the mu, kappa, and delta receptors. Compounds can have differing degrees of affinity and efficacy at these various receptors.

\section{Medicinal Uses and Toxicity of Thebaine and its Derivatives}

Alkaloids protect plants against bacteria, fungi, insects, and herbivores, as well as other plants by means of allelopathically active chemicals. Thebaine, or paramorphine, is a white, crystalline, 
slightly water-soluble, poisonous alkaloid. This alkaloid type is not used for therapeutic purposes but is converted to other compounds, such as buprenorphine, etorphine, oxycodone, oxymorphone, and naloxone. Thebaine derivatives are used for different purposes. 5[alpha])-6,7,8,14-tetradehydro-4,5-epoxy-3,6-dimethoxy-17methylmorphinan is more toxic and is about ten times higher than morphine. Also, it is the most poisonous opium alkaloid. Because of this reason, thebaine is used only for synthesis into other pharmaceutical drugs. Usually, thebaine readily undergoes DielsAlder reactions with various dienophiles to form into adducts.

The diene system of thebaine could potentially be attacked from both sides, but reactions with dienophiles always occur from the same face as the nitrogen bridge (upper face) due to the nitrogen bridge causing the lower face to be hindered through concealment inside a concave system [9]. The nature of a substituent in positions 7,8 of morphine alkaloids is among the most important factor affecting their biological activity [10]. The opioid analgesic buprenorphine, ethorphine possesses a pharmacological profile that may be interesting for development of antinarcotics [11]. Our previous reports show that cinnamaldehyde, a plant derivative, is an allergen, and it induces toxicity $[12,13]$. In this regard, an attempt has been carried out to evaluate the toxicity of thebaine, an allergen [14].

\section{Assessment of Chemical and Biochemical Activities of Thebaine Derivatives}

Hashish capsule (Papaver semniferum L.) contains nearly thirty kinds of alkaloids. Among this morphine, thebaine, papaverin and codeine are important to medicine raw materials that have medicinal value. In pharmacy, thebaine cannot be used directly as a drug because it exhibits toxicity but thebaine has a very important role as the main material with some reasons $[15,16]$.
These reasons include its view availability, its lower cost and chemical structure, containing a conjugated diene system at ring $\mathrm{C}$. The chemical structure of thebaine has allowed the preparation of many pharmaceutical products by Diels-Alder cycloadditions with a large number of dienophiles. Further, classical examples of drugs prepared using this approach are Etorphine [17] (Immobilon), Buprenorphine [18] (temgesic, buprenex, Buprex, Prefin) and many other adducts, reported mainly by Bentley [19-21] (Figure 6). Surprisingly, no references are found in the literature on the cycloaddition to thebaine of the dienophile that are various benzylidene malononitrile (1-28) and metilen malononitrile (2938), (Table 3).

Therefore, we firstly performed PM3 and DFT methods to evaluate the best dienophiles by using Gaussian09 [22] and Discovery Studio 3.5, (DS 3.5) [23]. In the meantime, we examined the effect of dienophile substitution (38 molecules) on the reactivity to select the substituents leading to the most favourable suitable reaction conditions. Then, novel and efficient addition products (Table 4) were analysed by using quantum chemical descriptors [24] for investigation of the differences in stereochemistry and determination of the energetically more suitable reactions. The quantum chemical descriptors have proven useful for the prediction of many molecular biological and physicochemical properties of interest to the pharmaceutical industry [25-27]. In conclusion, the obtained results about the known basic structure, 2-methylenemalononitrile, (MMN) (Figure 7), and the 38 molecules (Table 4) are evaluated to obtain a better understanding of the relationship between structure and activity. The same process is also applied to the novel addition products (Table 5), basing on thebaine and known drugs such as etorphine [17], buprenorphine [18], (Figure 6).

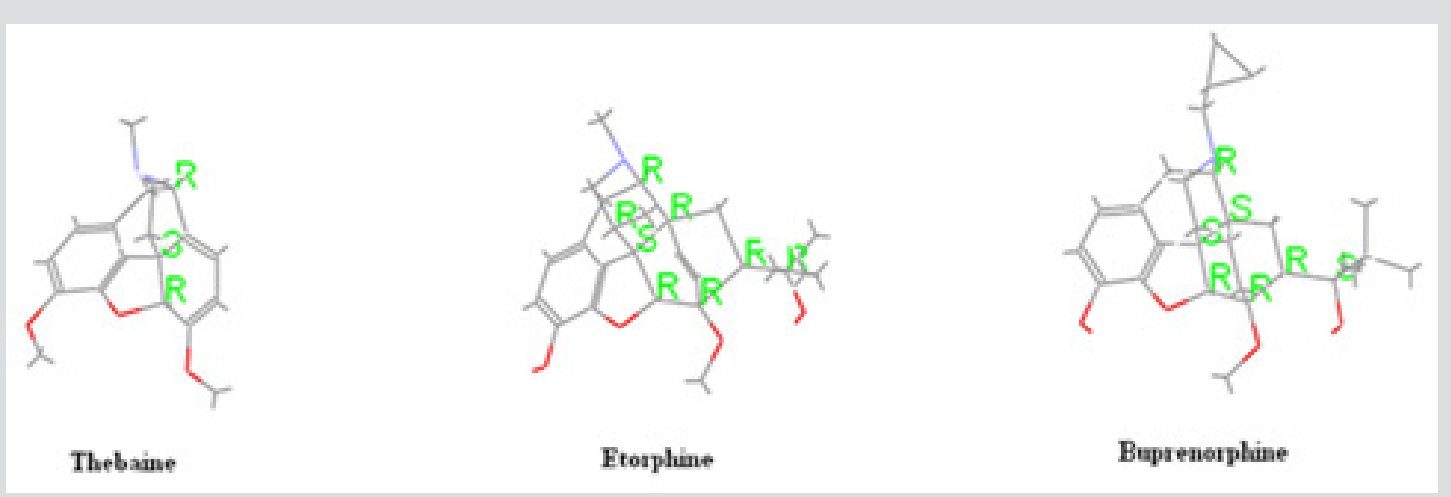

Figure 6: Three dimensional structures and absolute configurations of thebaine, etorphine and buprenorphine.

\section{Materials and Methods}

Thebaine has similar anesthetic activity as morphine, but it is very toxic and is obtained very little, compared to morphine. These reasons are generated from different searches on chemical modification of thebaine to eliminate and diminish side effects and also to increase the activity. Firstly, the various benzylidene malononitrile (1-28) and metilen malononitrile (29-38), (Table 4) as dienophiles, and possible semi-synthetic thebaine derivatives, $(38 * 8=304$ compounds) (Table 4$)$ were designed and optimized with semi-empirical PM3 and B3LYP/6-31G* level of theory in DFT methods by using Gaussian09 [22] and DS 3.5 [23] software. All stationary points were located and characterized as true minima by using both package programs with the semi-empirical PM3 and B3LYP/6-31G* basis sets. The calculated quantum chemical descriptors were total energy (E), the energy of the highest occupied molecular orbital (HOMO), the energy of the lowest unoccupied molecular orbital (LUMO), the global hardness ( $)$ ), electrophilicity index $(\omega)$, electronic charge $(\Delta N)$ and dipole moments $(D M)$. 
Tables 1 \& 2 for various dienophiles and Tables $3 \& 4$ for novel addition products were shown in Appendix. Furthermore, the calculated results were divided into two parts such as the dienophiles (Table 4) and novel addition products (Table 5). Each part was explained with figs (Figures 2-9). In the first part, the dienophiles were clarified based on 2-methylenemalononitrile (MMN) (Figure 7). In the second part, new thebaine derivatives were interpreted according to the obtained results with comparison to thebaine and known drugs such as etorphine [17], buprenorphine [18] compounds (Figure 6).

Table 4: The various benzylidene malononitrile and metilen malononitrile structures, as dienophiles (38 compounds).

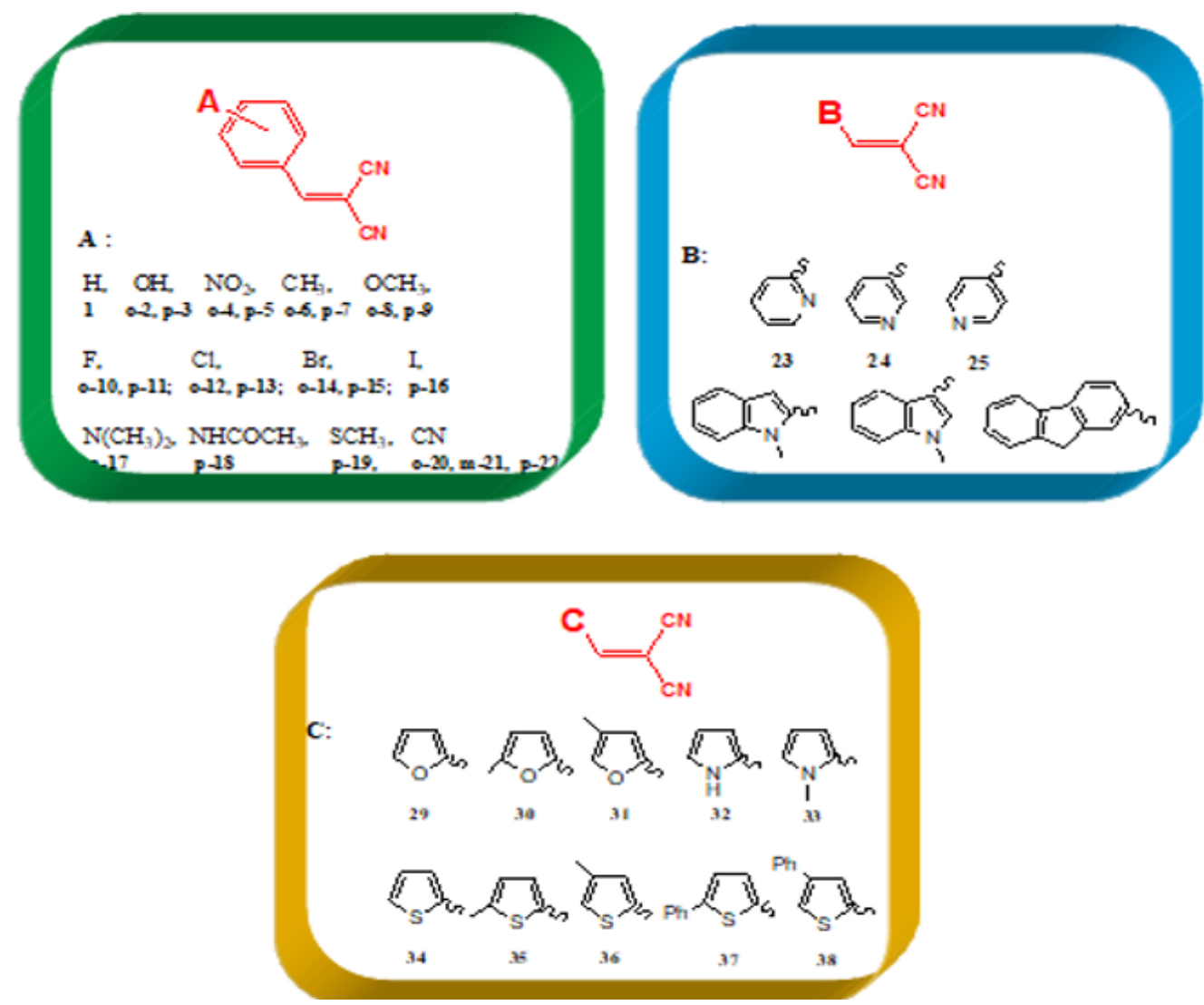

Table 5: The Novel Diels-Alder adducts that obtained [4+2] addition of several dienophiles (1-38) and thebaine, such as 2-(4-nitrobenzylidene) malononitrile for which there are eight configurations in D-A adducts.
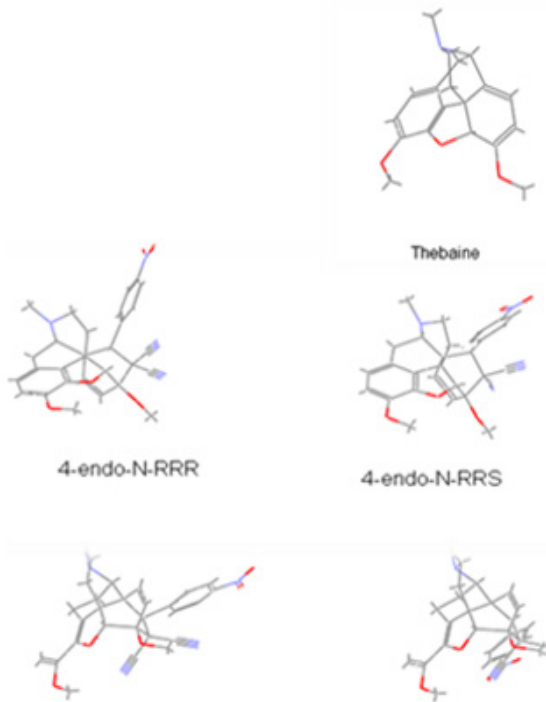

4.exo-N-SSR

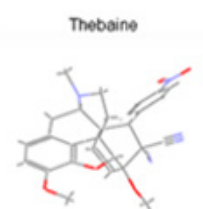

4.endo-N-RRS

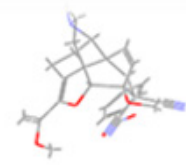

4-exo-N-SSS

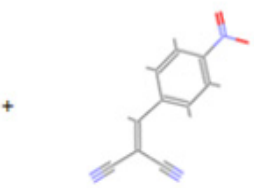

2-(4-nitrobenaydidene)matononitrile

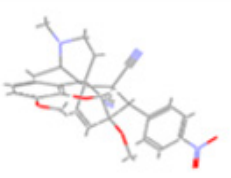

4.endo-RSR

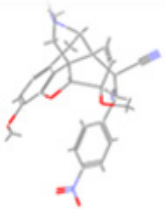

4.exo-SRR

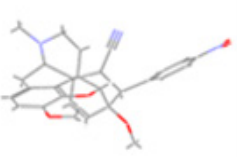

4-endo-RSS

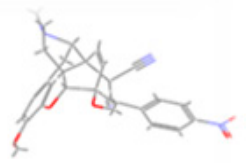

4.exo-SRS 


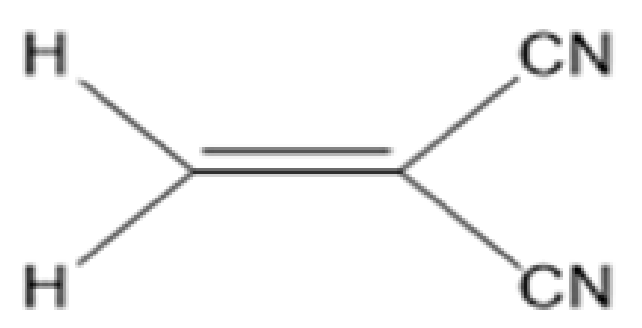

Figure 7: The chemical structure of 2-methylenemalononitrile (MMN).

\section{Results and Discussion}

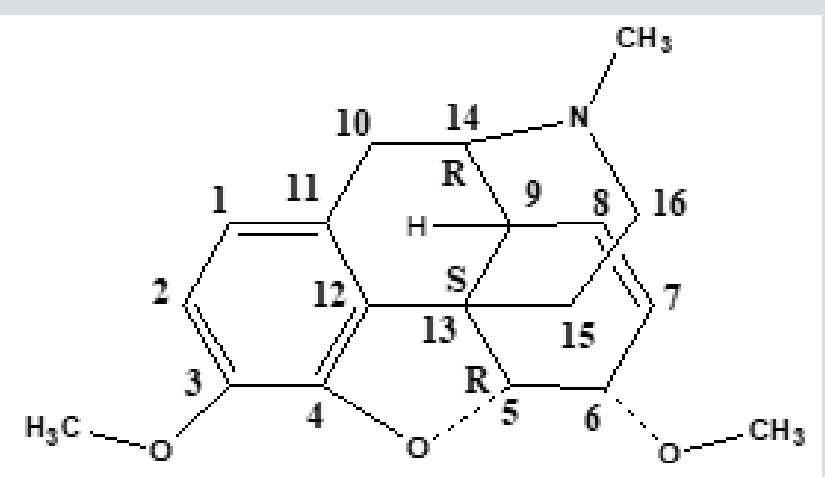

Figure 8: The absolute stereochemistry of thebaine, (C19H21NO3).

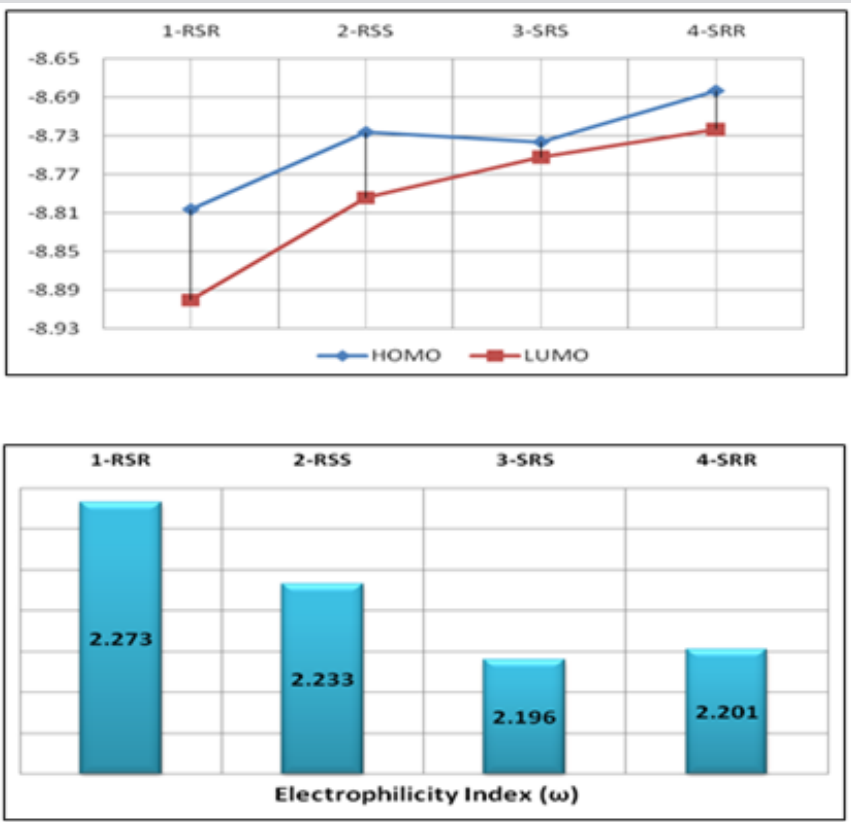

Figure 9: The plots of A. HOMO-LUMO gap B. Electrophilicty index, $(\omega)$ of possible configurations of thebaine.

In the literature, the activity value and active configuration of thebaine were 2.51 and RSR form (Figure 8). Because of this, all possible configurations of thebaine were drawn and optimized the PM3 level of a semi-empirical method by using DS 3.5 [23] and Gaussian09 [22]. It is indicated that RSR form of thebaine was more stable than others with the help of various quantum chemical descriptors such as HOMO, LUMO and electrophilicity index, $(\omega)$,
(Figure 1). Also, the difference between HOMO and LUMO of RSR configuration of thebaine has rather bigger magnitudes. The calculated electrophilicity index value of thebaine is also 2.273. As a result, all descriptors are validated and represent the stability of RSR form of thebaine in all possible configurations of thebaine. In the other words, theoretical calculations favor the experimental results of thebaine in literature (Figure 9). 


\section{The various dienophiles (1-38):}

According to the obtained data from Gaussian09 and DS 3.5 software, the global hardness $(\eta)$, electrophilicity index ( $\omega)$, and electronic charge $(\Delta N)$ values were calculated for the dienophiles (Table 3), and MMN (Figure 7). These results are listed in Figures 10-13. Within Table 1, there are three frames including six or fivemembered aromatic heterocycles monosubstituted by electronacceptor and -donor groups. These frames are entitled A, B and C. The structural as well as electronic characteristics induced by chemical substitution are because of the different responses of the global electrophilicity power. For instance, 2-(4-nitrobenzylidene) malononitrile, ( $\mathrm{p}-5)$ has a prominent difference for all quantum chemical descriptors in all dienophiles (1-38) and MMN. Because nitro is a strong electron-withdrawing group, it increases the electrophilic character. The -NO2 substituted benzylidene malononitrile structures, (o-4; p-5) have also shown the highest tendency in the electrophilicity index $(\omega)$ and electronic charge $(\Delta N)$ values. The second higher electrophilicity index $(\omega)$ value belongs to - $\mathrm{CN}$-substituted structures (p-22).

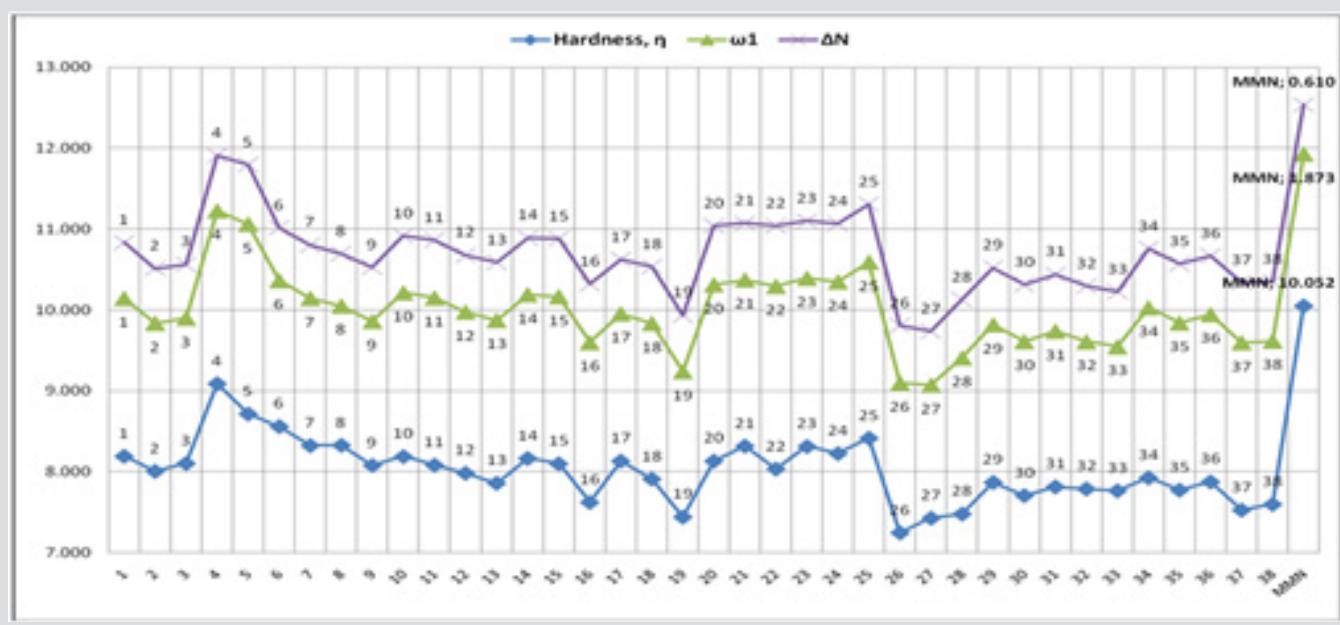

Figure 10: The global hardness $(\eta)$, electrophilicity index $(\omega)$ and electronic charge $(\Delta N)$ of selected compounds, (1-38) and 2-methylenemalononitrile, (MMN) were obtained PM3 method by using Gaussian 09 software.

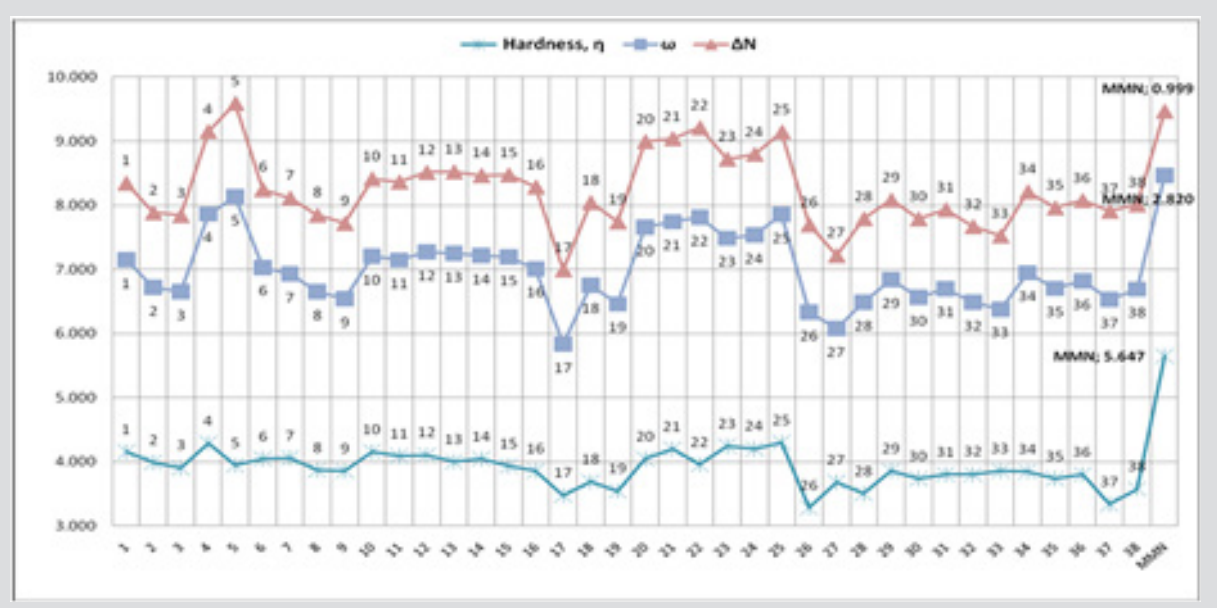

Figure 11: The global hardness $(\eta)$, electrophilicity index $(\omega)$ and electronic charge $(\Delta N)$ of selected compounds (1-38) and 2-methylenemalononitrile, (MMN) were obtained B3LYP / 6-31G* level of theory in DFT method by using Gaussian 09 software.

Meanwhile, other descriptors favor this opinion, (Figures 10 \& 11). On the contrary, the global hardness ( $\eta$ ) value shows the lowest trend on $\mathrm{A}, \mathrm{B}$, and $\mathrm{C}$ frame shapes. In the first structure $\mathrm{A}$, for 2-benzylidenemalononitrile (1), has higher electrophilicity index $(\omega)$ and electronic charge $(\Delta N)$ values, $[\omega: 1,949 ; \Delta N: 0,690]$ compared to MMN as standard reagent [ $\omega: 1,873 ; \Delta \mathrm{N}: 0,610]$. For 2-benzylidenemalonitrile (1), the substitution of a hydrogen atom by a strong electro-donor group, such as $-\mathrm{OH},(\mathrm{o}-2 ; \mathrm{p}-3)$ reduces the electrophilic character. Likewise, upon substitution of the hydrogen atom by different electro-donor groups (-CH3 (o-6; p-7) and -OCH3 (o-8; p-9)), the electrophilicity power further decreases. The -I (p-16), -Cl (o-12; p-13), -Br (o-14), -F (o-10), -Br (p-15), and -F (p-11) substituents classified in increasing order of electrophilicity power ( $\omega$ ), (Figure 10). As known, when the chemical substitution in the dienophile groups is increased by electro-donor groups, global electrophilic character decreases.

For example, (E)-2-methyl-3-(1-methyl-1H-indol-3- yl) acrylonitrile $(\mathrm{p}-27)$ has the worst behaviour of all quantum chemical descriptors in all dienophiles (1-38) and MMN. On the other hand, when electro-withdrawing groups (-SCH3, -N(CH3)2, 
-NHCOCH3, and -CN)s' electrophilicity power further increases, it indicates an increase of reactivity towards a nucleophile. In addition to this, para position in any structure is preferred rather than ortho and meta positions for all dienophiles (1-38). As with the benzylidene analogues, replacement of pyridine $(23,24,25)$, indole $(26 ; 27)$ and carbazole $(28)$ in second group B, compound 25 , which contains nitrogen group is also placed in a para position, exhibits good activity in others, (Figure 10), (see detail information Table 1 in Appendix.). In the last group C, including five-membered aromatic heterocycles monosubstituted by electron-acceptor and -donor groups, (Figure 10) demonstrates the decreasing order of electrophilicity index $(\omega)$ and electronic charge $(\Delta N)$ values, (thiophene > furan > pyrrole), respectively.

For furan and thiophene compounds, the substitution of a hydrogen atom by an electro-donor group, $-\mathrm{CH} 3$, gives increase when - CH3 places to meta position instead of ortho position. However, upon substitution of a hydrogen atom on nitrogen by $-\mathrm{CH} 3$, decreases the activity based on the pyrrole. If $-\mathrm{CH} 3$ is replaced with -Ph group, these structures $(37,38)$ have the higher increase in group $\mathrm{C}$. In addition, it mentioned nearly the same trend for the dienophiles and MMN at B3LYP/6- 31G* level of theory in DFT method by using Gaussian 09 software (Figure 11). At the same time, the global hardness $(\eta)$, electrophilicity index $(\omega)$, and electronic charge $(\Delta N)$ values were calculated for the dienophiles and MMN by using DS 3.5 software (Figures 12-13). As a result, the same behaviours of investigated compounds are shown (Figure 10 vs. Figure 12). Also, these results are rational and coherent for the various dienophiles and MMN, according to different methods such as PM3 and B3LYP/6-31G* level of theory in DFT methods by using Gaussian 09 software and PM3/VAMP and BLYP/DMol3 methods by using DS 3.5 software.

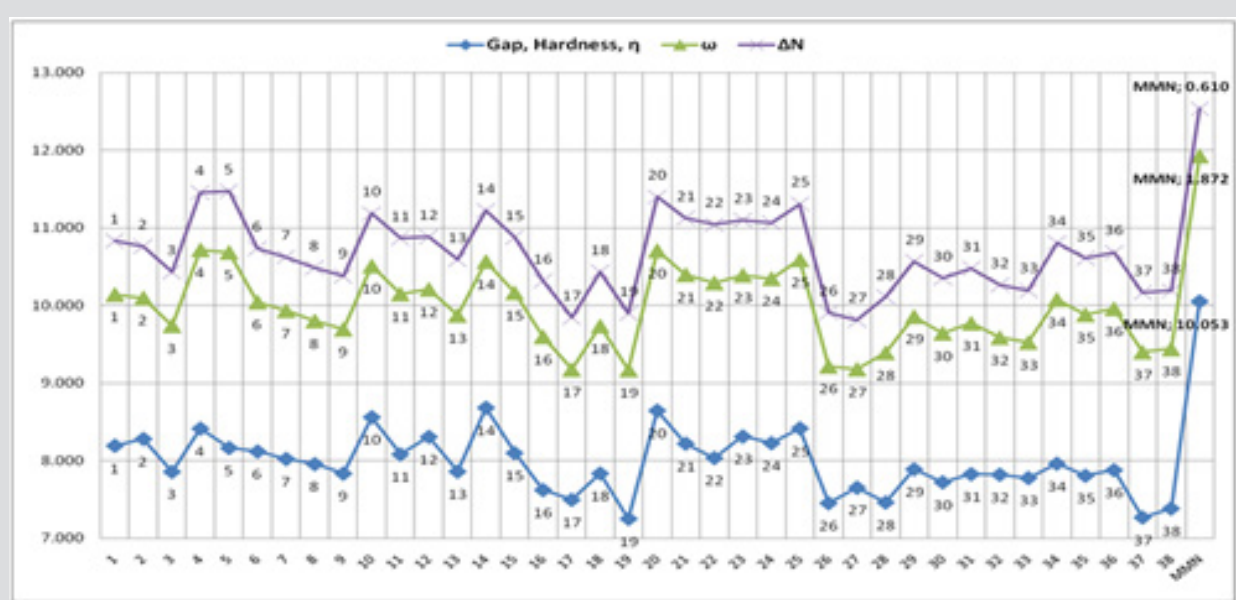

Figure 12: The global hardness $(\eta)$, electrophilicity index $(\omega)$ and electronic charge $(\Delta N)$ of selected compounds, (1-38) and 2-methylenemalononitrile, (MMN) were obtained at PM3/VAMP method by using DS 3.5 software.

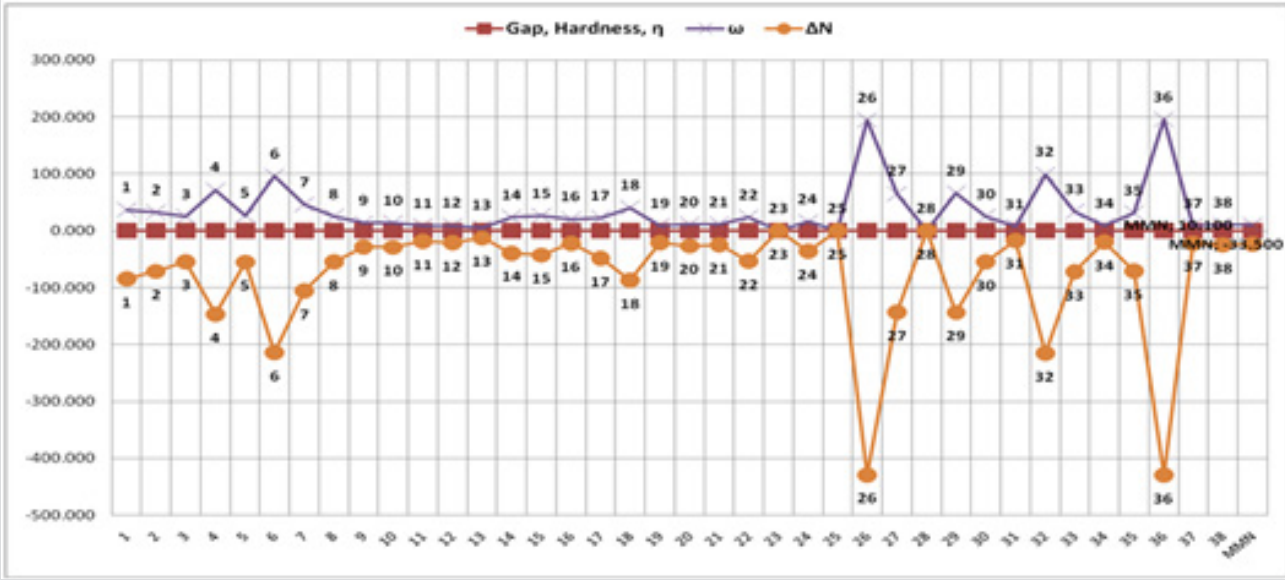

Figure 13: The global hardness $(\eta)$, electrophilicity index $(\omega)$ and electronic charge $(\Delta N)$ of selected compounds, (1-38) and 2-methylenemalononitrile, (MMN) were obtained at BLYP/DMol3 method by using DS 3.5 software.

In particular, the obtained results with PM3 and PM3/VAMP methods have similar numerical values and trends (Figures 10 \& 12). However, there are logical and possible results with B3LYP/6$31 \mathrm{G}^{*}$ basis set (Figure 11). The results with BLYP/DMol3 method by using DS 3.5 software shows inconsistent and lacking correct logical relation data for the dienophiles and MMN (Figure 13).
Furthermore, PM3 method in Gaussian 09 program is implemented for additional novel products in the further process of our work, because PM3 and PM3/VAMP methods in Gaussian 09 and DS 3.5 software have similar behaviour. However, BLYP/DMol3 method by using DS 3.5 software also exhibits extraordinary results. In Gaussian 09 software, PM3 and B3LYP/6-31G* levels of theory in 
DFT methods show consistency in their results, but the additional novel products are not suitable for analysis at B3LYP/6-31G* level of theory in DFT method by using Gaussian 09 program, due to rather huge and steric groups of studied compounds, (molecular weight: $400-600 \mathrm{~g} / \mathrm{mol})$.

\section{Novel Addition Products}

In the second part of the study, we first investigate and understand the differences in stereochemistry and predict the reactivity of thebaine and its novel and efficient addition products (Table 4) by using quantum chemical descriptors [24]. The new thebaine derivatives were evaluated according to the obtained results with comparison to thebaine and known drugs, (Figure
6). The calculated descriptors of thebaine and known drugs were also given in Figure 14. Moreover, the diene system of thebaine could potentially be attacked from both faces, yet reactions with dienophiles occur from the same face as the nitrogen bridge (upper face) due to the nitrogen bridge causing the lower face to be hindered through concealment inside a concave system. Thus, all possible configurations of additional novel products were computed at PM3 method by using Gaussian 09 software (Figure 15). This method was selected based on its attainable, suitable, and rational results in the former calculations for dienophiles (Table 3). It is known that global hardness provides information about stabilities of compounds [24].

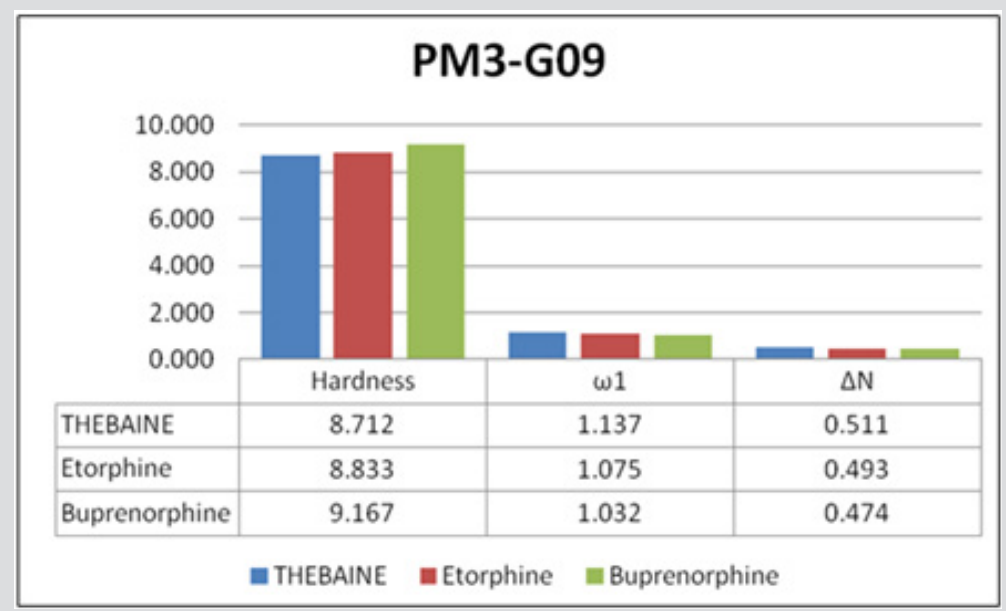

Figure 14: The quantum chemical descriptors' values of thebaine and known drugs such as thebaine, etorphine and buprenorphine structures.

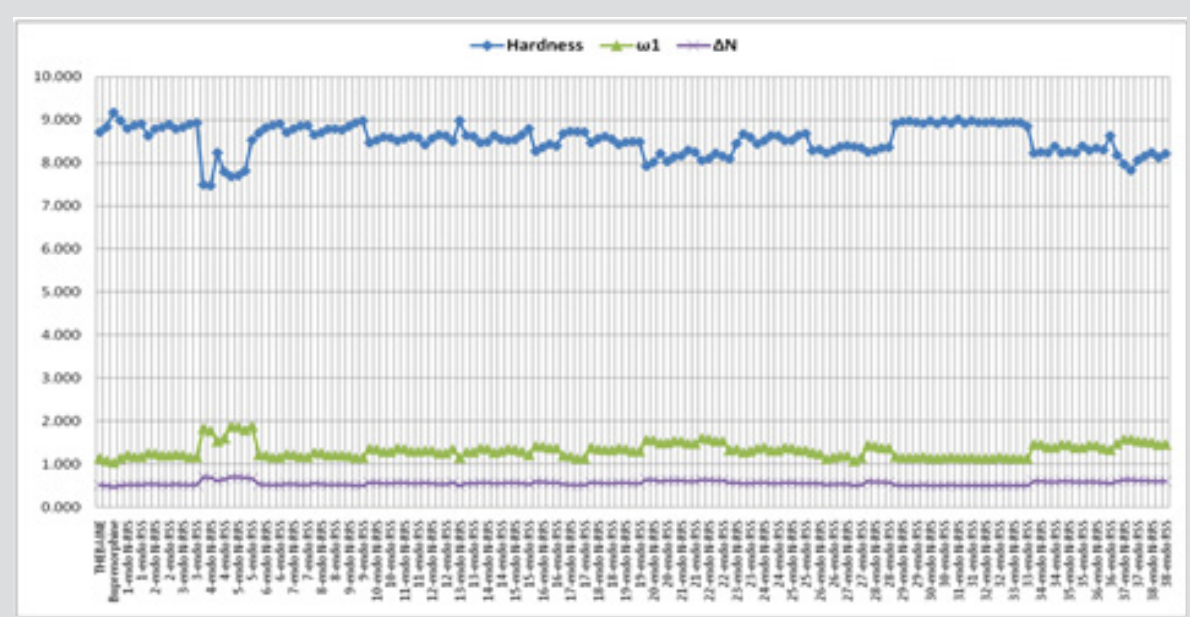

Figure 15: The global hardness $(\eta)$, electrophilicity index, $(\omega)$ and electronic charge $(\Delta N)$ of additional novel products $\left(38^{*} 4=\right.$ 152 compounds, Table 2) were obtained by PM3 method by using Gaussian 09 software

Electrophilicity index provides comprehensive information about the structure, properties, stability, reactivity, interactions, bonding, toxicity, and dynamics of many-electron systems in ground and excited electronic states [27]. With respect to the obtained results, Figure 16 exhibited the trend of three quantum descriptors values of possible eight configurations of 2-benzylidenemalononitrile (1) in 6-ring compounds and 2-furan2-ly-methyl malononitrile (29) in 5-ring compounds in comparison to thebaine and known drugs. (See detail information Tables $3 \& 4$ for additional novel products in Appendix.) It showed that endoforms of 6- and 5-ring compounds were more stable than exoforms and more effective than thebaine and known drugs. As expressed above, endo forms of novel addition compounds were more stable than exo-form; thus endo forms of the compounds were separated in data. Then, the compounds include electron-withdrawing groups, exhibited better performance than the compounds that include 
electron-donating groups, such as -NO2 versus - $\mathrm{OH}$. Afterwards, all investigations were applied only to the selected compounds.

These were $4,5,10-16,20-25,34,37,38$, given as Table 5 in Appendix and the obtained results were represented in Figure
17. The Figure 17 shows that endo forms of 4 and 5 compounds have predominant properties compared to others in all quantum chemical descriptors. Also, the selected compounds were more effective than thebaine and known drugs (Figure 6).

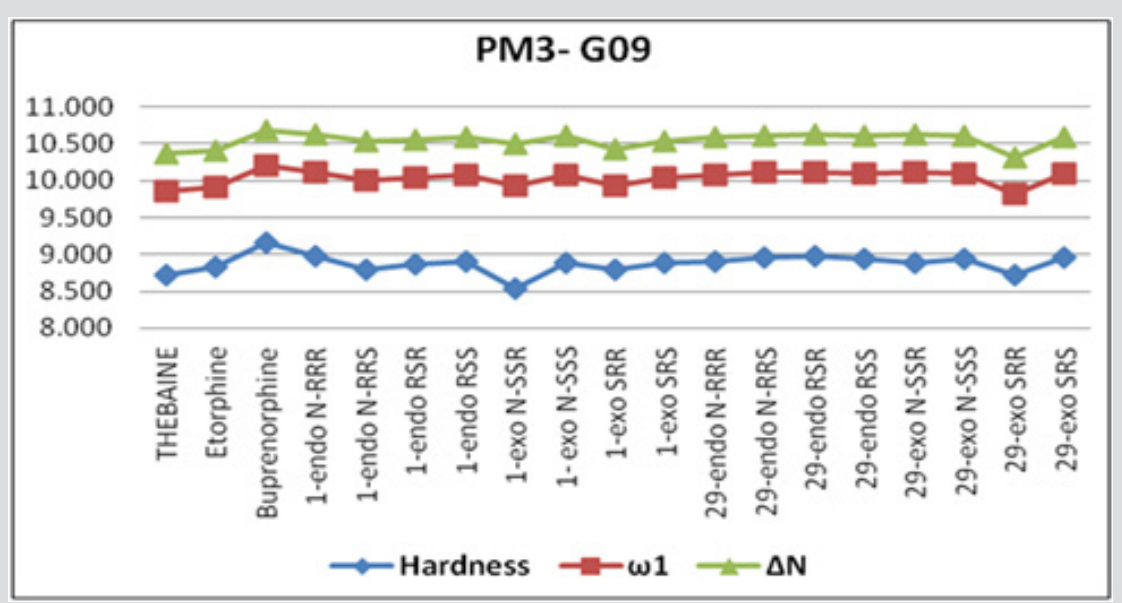

Figure 16: The global hardness $(\eta)$, electrophilicity index $(\omega)$, and electronic charge $(\Delta N)$ values of the possible eight configurations products of 2-benzylidenemalononitrile (1) and 2-Furan-2-ly-methyl malononitril (29).

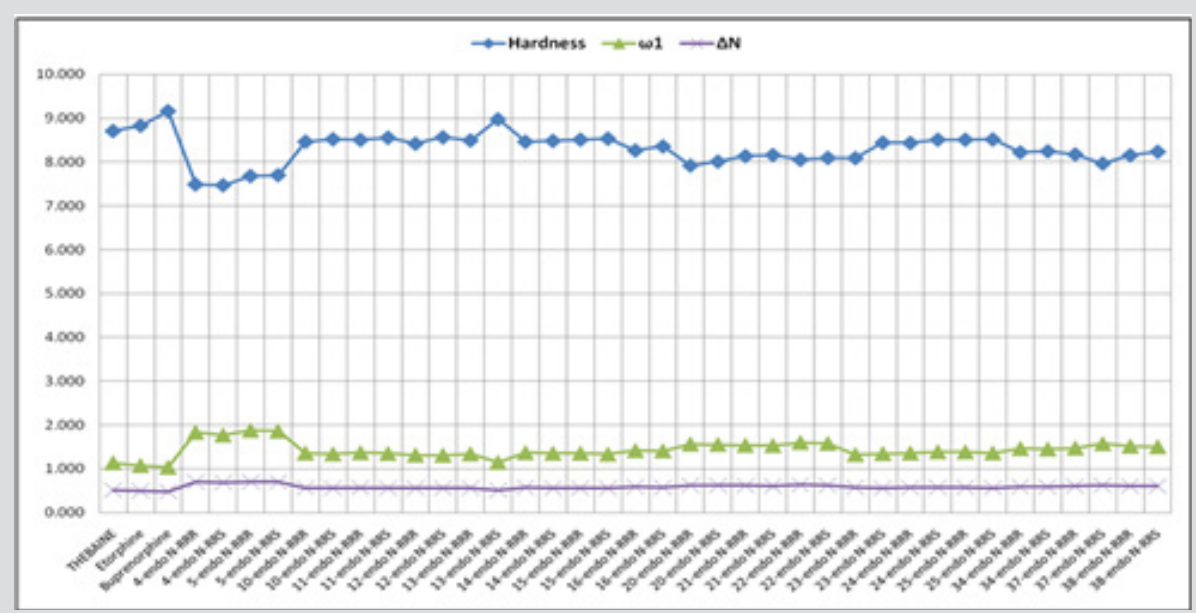

Figure 17: The global hardness $(\eta)$, electrophilicity index $(\omega)$ and electronic charge $(\Delta N)$ of addition novel products $\left(18^{*} 4=72\right.$ Compounds, Scheme 3) were obtained in PM3 method by using Gaussian 09 software.

\section{Conclusion}

In summary, the global electrophilicity index introduced by Parr et al. [28-30] becomes a useful means of understanding the substituents in the diene/dienophile interacting pair. It also provides a way to classify the electrophilicity power of a series of dienophiles, the addition novel products of thebaine. Upon increasing dienophile substitution with electro-withdrawing groups, -F, -Cl, -Br, -I, (10-16), -CN, (20-22), and -NO2 (4-5) substituents, there is an increase in $\omega$ index, thus reflecting a higher electrophilic character. The structural and electronic characteristics induced by chemical substitution are due to different responses of the global electrophilicity power. The influence of the combination as well as the positional relationship of the substituents of each dienophile and the addition novel products can be analysed to develop most suitable reactions for the design of possible precursor to be integrated into synthetic sequences. Results are in agreement with those experimentally developed for each diene/dienophile pair in D-A reactions. Depending on the observed global hardness $(\eta)$, electrophilicity index $(\omega)$, and electronic charge $(\Delta N)$ values, it can be assumed that for various benzylidene malononitrile and metilen malononitrile, the substitution of a hydrogen atom by a strong electro-withdrawing group, such as nitro -NO2 (4-o and 5 -p), gives rise to an increase of the electrophilic character.

\section{Acknowledgements}

The authors acknowledge Y. Yildirir and F. Sevin Duz for data collection and E. Aki-Yalcin and ESIS research group for technical support. 


\section{References}

1. Lovell BE, Butterfield WJH, Mc Gehee HA, Heptinstall RH, Lewis T (1986) International Dictionary of Medicine and Biology. John Wiley \& Sons, New York, USA, 14(1): 118.

2. Ladenburg A (1881) Die Natürlich vorkommenden mydriatische wirkenden Alkaloide. Ann Chem Pharm 206: 274-307.

3. Roberts MF, Wink M (1998) Alkaloids: Biochemistry, ecology and medicinal applications. Plenum Press, New York and London 62(4): 664

4. Pelletier SW (1983) The nature and definition of an alkaloid, in Alkaloids Chemical and Biological Perspectives. Wiley, New York, USA, p. 1-31.

5. Stoelting RK (1991) Pharmacology, Physiology \& Anesthetic Practice. ( $2^{\text {nd }}$ edn.). Lippincott Williams \& Wilkins, Baltimore.

6. Meldrum ML (2003) A capsule history of pain management. JAMA 290(18): 2470- 2475

7. Klockgether Radke APFW (2002) Sertürner and the discovery of morphine. 200 years of pain therapy with opioids. Anasthesiologie, Intensivmedizin, Notfallmedizin, Schmerztherapie: AINS (in German) 37(5): 244-249.

8. Davis MP, Le Grand SB, Lagman R (2005) Look before leaping: combined opioids may not be the rave. Support Care Cancer 13(10): 769-774.

9. Maat L, Woudenberg RH, Meuzelaar GJ, Linders JT (1999) Chemistry of opium alkaloids. Part 44: Synthesis and opioid receptor binding profile of substituted ethenoisomorphinans and ethenomorphinans. Bioorg Med Chem 7(3): 529-541.

10. Lenz GR, Evans SM, Walters DE, Hopfinger AJ (1986) Opiates, Academic Press, London, p. 65.

11. Lewis JW (1985) Buprenorphine, Drug Alcohol Depend 14(3-4): 363372.

12. Gowder SJT, Devaraj H (2008) Food flavor cinnamaldehyde -induced biochemical and histological changes in the kidney of male albino wistar rat. Environ Toxicol Pharmacol 26: 68-74.

13. Gowder SJT, Devaraj H (2006) Effect of food flavor cinnamaldehyde on the antioxidant status of rat kidney. Basic Clin Pharmacol Toxicol 99(5): 379-382.

14. Ríos JL, Bas E, Recio MC (2005) Effects of Natural Products on Contact Dermatitis. Curr Med Chem- Anti-Inflammatory \& Anti-Allergy Agents 4(1): 65-80.

15. Bentley KW (1954) The Chemistry of the Morphine Alkaloids, Oxford University Press, London, p. 184.

\section{ISSN: 2574-1241}

DOI: 10.26717/BJSTR.2019.17.002993

Sivakumar JT Gowder. Biomed J Sci \& Tech Res

This work is licensed under Creative Commons Attribution 4.0 License

Submission Link: https://biomedres.us/submit-manuscript.php
16. The Merck Index (1976) Rahway, Merck \& Co, $\left(9^{\text {th }}\right.$ edn.). New Jersey, USA, $339,458,826,1194$.

17. Bentley KW (1971) The Alkaloids, Chemistry and Pharmacology. RH F Manske, Holmes HL (Eds.); Academic Press: New York, USA, 13(75).

18. Lewis JW (1985) Discovery of Buprenorphine, a Potent Antagonist Analgesic. In Medicinal Chemistry. The Role of Organic Chemistry in Drug Research; Roberts SM, Price BJ, (Eds.) Academic Press, London, p. 19.

19. Bentley KW, Hardy DG, Meek B (1967) Novel analgesics and molecular rearrangements in the morphine-thebaine group. II. Alcohols derived from 6,14-endo-etheno- and 6,14-endo-ethanotetrahydrothebaine. J Am Chem Soc 89(13): 3273-3280.

20. Bentley KW, Hardy DG, Meek B (1967) Novel analgesics and molecular rearrangements in the morphine-thebaine group. IV. Acid-catalyzed rearrangements of alcohols of the 6,14-endo-ethenotetrahydrothebaine series. J Am Chem Soc 89(13): 3293-3303.

21. Bentley KW, Hardy DG, Meek B (1967) Novel analgesics and molecular rearrangements in the morphine-thebaine group. VI. Base-catalyzed rearrangements in the 6,14-endo-ethenotetrahydrothebaine series. J Am Chem Soc 89(13): 3312-3321.

22. Frisch MJ, Trucks GW, Schlegel HB, Scuseria GE, Robb MA, et al. (2011) Gaussian 09, Revision C.01, Gaussian, Inc., Wallingford CT, England.

23. Accelrys Software Inc (2013) Discovery Studio 3.5, San Diego, USA.

24. TaskinT, Sevin F (2007) Theoretical investigation on Chemical and Biological Activities of 5,6-dihydro-11H-benzo[a]carbazole and Its Derivatives. Journal of Molecular Structure: THEOCHEM 803(1): 61-66.

25. Parr RG, Szentpaly LV, Liu S (1999) Electrophilicity Index. J Am Chem Soc 121(9): 1922-1924.

26. Maynard AT, Huang M, Rice WG, Covell DG (1998) Reactivity of the HIV1 nucleocapsid protein $\mathrm{p} 7$ zinc finger domains from the perspective of density-functional theory. Proc Natl Acad Sci USA 95(20): 11578-11583.

27. Chattaraj PK, Roy DR (2011) Update 1 of electrophilicity index. Chemical Reviews 107(9): PR46-PR74.

28. Parr RG, Donnelly RA, Levy M, Palke WE (1978) Electronegativity: The density functional viewpoint. J Chem Phys 68: 3801-3807.

29. Parr RG (1983) Pearson, R.G. Absolute hardness: companion parameter to absolute electronegativity. J Am Chem Soc 105(26): 7512-7516.

30. Parr RG, Chattaraj PK (1991) Principle of maximum hardness. J Am Chem Soc 113(5): 1854-1855.

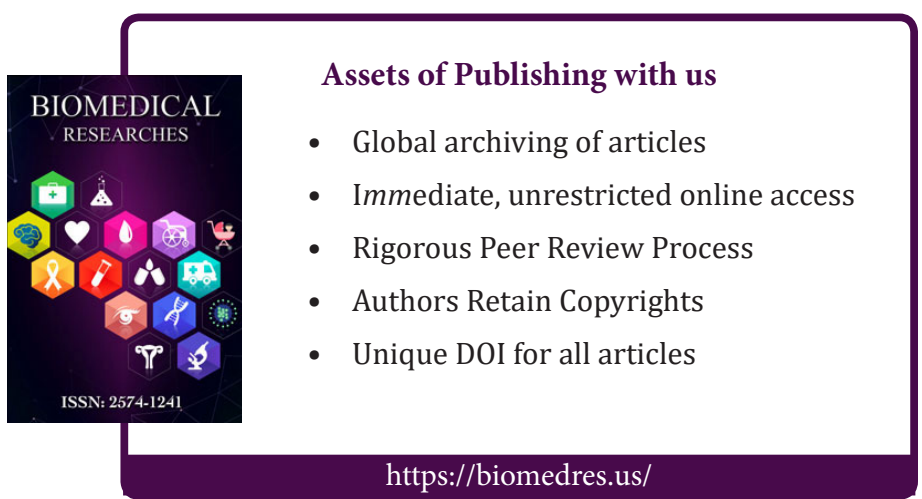

